American Journal of BioScience
2020; 5(1): $18-28$
http://www.sciencepublishinggroup.com/j/ajbio
doi: 10.11648 /j.ijbbmb.20200501.13
ISSN: $2330-0159$ (Print); ISSN: $2330-0167$ (Online)

\title{
Response of Head Cabbage (Brassica olearacea L.) Yield to Application of Different Rates of Inorganic Nitrogen and Phosphorus Fertilizers at Bore, Southern Ethiopia
}

\author{
Solomon Teshome*, Arega Amide \\ Oromia Agricultural Research Institute, Crop Research Process, Bore, Ethiopia \\ Email address: \\ solomtesh41@gmail.com(S. Teshome) \\ ${ }^{*}$ Corresponding author \\ To cite this article: \\ Solomon Teshome, Arega Amide. Response of Head Cabbage (Brassica olearacea L.) Yield to Application of Different Rates of Inorganic \\ Nitrogen and Phosphorus Fertilizers at Bore, Southern Ethiopia. American Journal of BioScience. Vol. 5, No. 1, 2020, pp. 18-28. \\ doi: $10.11648 /$ j.ijbbmb.20200501.13
}

Received: September 6, 2020; Accepted: September 22, 2020; Published: October 14, 2020

\begin{abstract}
The field trial was conducted during 2017 and 2018 main cropping season at the Bore Agricultural Research Centre which is located in Gudji Zones, of Southern Ethiopia to determine the effect of different application rates of nitrogen and phosphorus fertilizers on growth, yield and yield components of head cabbage and to identify their economically appropriate rates that maximize yield of head cabbage. The experiment was carried out to study cabbage variety Olsen to added $\mathrm{N}$ and $\mathrm{P}$ nutrients in respect to growth, yield and yield related parameters of the crop. The longest head initiation (90 days) and longest (140) days to maturity was attained in $294 \mathrm{~kg} \mathrm{ha}^{-1}$ Nitrogen and $138 \mathrm{~kg} \mathrm{ha}^{-1}$ phosphorus treatment, while shortest head initiation (64.33 days) was obtained in control treatment. The maximum plant height $(26.4 \mathrm{~cm})$ was recorded for the treatment T3P4 $\left(235+138 \mathrm{kag} \mathrm{h}^{-1}\right)$, while the lowest $(16.9 \mathrm{~cm})$ plant height was recorded from the T1P1 (control) treatment. Nutrient levels markedly influenced the diameter, height, head mass and yield of head cabbage. The maximum average head diameter $(25.44 \mathrm{~cm})$ and average height $(27.33 \mathrm{~cm})$ was recorded in treatment receiving $235 \mathrm{~kg} \mathrm{~N}$ and $82 \mathrm{~kg} \mathrm{P} \mathrm{ha}{ }^{-1}$. Combined application of $235 \mathrm{~kg} \mathrm{~N} \mathrm{ha}^{-1}$ with the $82 \mathrm{~kg} \mathrm{P} \mathrm{ha}^{-1}$ produced the highest $(2356.67 \mathrm{~g})$ untrimmed head weight of cabbage followed by second maximum (2133.33 g) untrimmed head weight with the rate of $235 \mathrm{~kg} \mathrm{~N}^{-1}$ with the $110 \mathrm{~kg} \mathrm{P}^{-1}$ while the least $(1120.67 \mathrm{~g})$ untrimmed head weight was recorded for the control treatment. Combined application of $235 \mathrm{~kg}$ nitrogen and $82 \mathrm{~kg}$ phosphorus ha ${ }^{-1}$ (N3P2) recorded maximum (69.00 t) head yield without wrapper ha ${ }^{-1}$ and the lowest $\left(27.66 \mathrm{t} \mathrm{ha}^{-1}\right)$ was recorded by control treatment. The marginal rate of returns, which determines the acceptability of any treatments shows that treatments that received $235 \mathrm{~kg} \mathrm{~N} \mathrm{ha}^{-1}$ in combination with $82 \mathrm{~kg} \mathrm{ha}^{-1}$ of P yielded $43498 \%$ marginal revenue. Therefore, this combined nutrient application rates can be recommended in the research area and similar agro-ecologies since it is the most feasible rates for the producers because of its low cost of production and higher benefits.
\end{abstract}

Keywords: Combined, Nitrogen, Nutrient, Olsen, Phosphorus, Treatment

\section{Introduction}

Head cabbage is scientifically known as Brassica oleracea var. capitata. It belongs to the Cruciferae family which includes also kale (Brassica oleracea var acephala), Chinese cabbage (Brassica pekinensis (Lour Rapr.) and Brussels sprouts (Brassica oleracea var. gemmifera DC). It was introduced initially to China before 2000 years ago, where the heading (Brassica oleoracea L) types were developed [38].

Cabbage thrives best during cool, moist seasons [11, 29,
35, 36]. Even though it requires $500 \mathrm{~mm}$ of water for its growing period [2], good drainage is important; as too much water tends to split heads when they are mature $[31,36]$. Water should not be deficient from head formation until harvest time, as this will drastically limit yields [2]. According to Lecuona it can be grown throughout the year and its optimum soil $\mathrm{pH}$ ranges from 6.0 to 7.0 [17]. Its growth season is between 80 to 100 days [10].

It has long been accepted that applications of nitrogen fertilizer to cabbage increased yields, plant uniformity, and 
quality [34]. To produce optimum yields of good quality cabbages, often high amounts of nitrogen fertilizer are applied. The recommended total amounts of nitrogen fertilizer for cabbage are 160 to $260 \mathrm{~kg} \mathrm{ha}^{-1}$. In reality, the amount of nitrogen fertilizer used is probably higher as farmers may apply more fertilizer than recommended to secure yields. Nitrogen produces reliable and optimal yield and quality of vegetables [16]. It is however, the most difficult element to manage in a fertilization system in order to ensure an adequate, yet not excessive, amount of available nitrogen within the rhizosphere from planting to harvest [1].

Nitrogen and phosphorus are one of the nutrients of major importance in the growth of head cabbage. Lack of these major nutrients causes the plant to be stunted and becomes yellow in appearance thereby decrease yield. An adequate supply of nitrogen is essential for vigorous vegetative growth, head formation and optimum yield of cabbage [37]. However, the response of the crop to nitrogen and phosphorus varies under different soil and agro climatic conditions and thus affecting the optimum level of nitrogen and phosphorus. Achieving and maintaining appropriate levels of soil fertility, especially plant nutrient availability, is of paramount importance in agricultural land to remain capable of sustaining crop production at an acceptable level.

In the past, agricultural production was focused on maximizing the quantity of vegetables produced for commercial market while in the last few decades the organic management of crops has gained great popularity because of increased consumers' awareness of the health problems that come from food grown under conventional and intensive farming. Differences between organic and conventional farming systems, especially in soil fertility management, may affect the nutritive composition of plants. Soils vary in their capacity to provide nutrients to crops and crops differ in their requirements, therefore, most soils cannot supply all essential nutrients to crops [26]. Fertilizers recommendations are therefore, developed to quantify the amount of nutrients for various crops which are to be applied through fertilizers. Therefore the activity was proposed to determine the effect of different application rates of nitrogen and phosphorus fertilizers on growth, yield and yield components of head cabbage and to identify their economically appropriate rates that maximize yield of head cabbage.

\section{Literature Review}

\subsection{Origin, Importance and Ecology}

Cabbage originated from a wild non-heading type, 'Cole wart' (Brassica oleracea var. sylvestris). The genus Brassica includes about 100 species, majorities of which are native to the Mediterranean region. The crop is attributed to Mediterranean center of origin. It is also considered that the real headed cabbage was evolved in Germany. The Savoy (yellowish green) cabbage originated in Italy and spread to France and Germany in the sixteenth and seventh centuries [18]. The cabbage seems to have originated in Europe around 1000BC, after which it was introduced into the Middle East and other areas. Today, cabbages can be found all around the world, making is possible for everyone to experience its benefits [4].

Today, China is the largest producer of cabbage, followed by India and Russia, which is the biggest consumer of cabbage. Around the world, cabbage is prepared in different ways. While it can be eaten raw, as a salad, cabbage can be steamed, pickled, stewed, sautéed or braised. Sauerkraut and kimchi are the most popular pickled variants while the coleslaw is one of the most popular salads. Cabbage is a leafy vegetable from the wide family of "brassicas". It is grown annually, and we eat its dense green or purple leaves in many different dishes. Head of cabbage, which can grow from 0.5 to 4 kilograms, is rich in vitamins and minerals, has almost no fat and is very rich in fiber which makes it very healthy to eat. Cabbage health benefits includes reducing risk of cancer, improving brain and nervous system health, promoting bone health, maintaining blood pressure, detoxifying the body, promoting bowel regularity, regulating sugar level and promoting weight loss. Other benefits includes improving health of hair, skin and nails, helping prevent or heal acne, healing stomach ulcers, helping care for the heart, promoting healthy pregnancy and boosting immunity [4].

It thrives in well-drained, moisture-retentive, loamy soils well supplied with organic matter. It does not grow well in highly acidic soil. The ideal soil $\mathrm{pH}$ ranges from 5.5 to 6.5 and it should not be allowed to drop below 4.5. Cabbage can be grown easily under a wide range of environmental conditions but cool moist climate is most suitable. The optimum soil temperature for seed germination is $22-26.2^{\circ} \mathrm{C}$. The optimum temperature for growth is between 25.2 to $34.2^{\circ} \mathrm{C}$. Whereas, temperature above $43.2^{\circ} \mathrm{C}$, growth is arrested in most of the cultivars. Cabbage plants that are exposed to temperatures of $10-13^{\circ} \mathrm{C}$ for prolonged periods will produce premature seed stalks instead of heads [30].

\subsection{Response of Vegetables to Nutrient Application}

Vegetable producers use manures, organic residues and other wastes as an alternative source of fertilizer to produce vegetable crops. However, these organic materials are not processed and applied as a raw. Experiments done in India showed that treatment combinations with organic and inorganic fertilizers recorded significantly higher cabbage head yield $\left(42.42 \mathrm{t} \mathrm{ha}^{-1}\right)$ over the control with an addition of $150 \mathrm{~kg} \mathrm{~N} \mathrm{ha}^{-1}$ fertilizer in combination with $10 \mathrm{t}$ ha-1 FYM over the control head yield $\left(38.10 \mathrm{t} \mathrm{ha}^{-1}\right)$. In another field experiments the application of $240 \mathrm{~kg} \mathrm{~N}, 45 \mathrm{~kg} \mathrm{P}, 180 \mathrm{~kg} \mathrm{~K}$ and $45 \mathrm{~kg} \mathrm{~S} \mathrm{ha}^{-1}$ performed best in recording plant height, root length, number of loose leaves and heading leaves, leaf length and breadth, thickness and diameter of head and yield. The maximum marketable yield $\left(87.09 \mathrm{t} \mathrm{ha}^{-1}\right)$ was recorded in an application of $240 \mathrm{~kg} \mathrm{~N}, 45 \mathrm{~kg} \mathrm{P}^{-1}{ }^{-1}$ [3]. Lesic et al., reported that cabbage has high requirements for all nutrients, especially nitrogen and for achieving high yields it ranged from 130 to $310 \mathrm{~kg} \mathrm{~N} \mathrm{ha}^{-1}$ [18].

Cabbage has good responsiveness on animal manure application in quantity of $40 \mathrm{t} \mathrm{ha}^{-1}$. Organic fertilization 
enhances soil biological activity, improves nutrient mobilization and soil structure and increases soil water retention. Systems relying on organic fertilizers as plant nutrient sources have different dynamics of nutrient availability than those using mineral fertilizers. Sustainable crop production with integrated use of mineral and organic fertilizer has proved to be highly beneficial. Several studies have shown the positive effect of combined use of mineral and organic fertilizers in fields that continuously for a few years received only $\mathrm{N}, \mathrm{P}$ and $\mathrm{K}$, without any micronutrient or organic fertilizer $[5,15]$.

To produce optimum yields of good quality vegetables, often high amounts of nutrients are applied. However, it is usually not feasible to supply sufficient concentrations of essential plant nutrient elements to sustain plant growth for an extended period. The role of nitrogen in vegetable growth has been investigated in a number of vegetable crops. Generally, vigorous growth was attributed to higher nitrogen regimes [33]. Melton and Dufault studied the effect of various rates of nitrogen, phosphorous and potassium on 'Sunny' tomato transplant growth and transplant quality. It was observed that nitrogen was a major factor affecting tomato transplant growth in both years of research [20].

\subsubsection{Response of Head Cabbage to Nutrient Application}

Cabbage has high requirements for all nutrients, especially nitrogen, and cabbage demands for achieving high yields ranged from 130 to $310 \mathrm{~kg} \mathrm{~N} \mathrm{ha}^{-1}[18,26]$. Nitrogen over use in modern agriculture is of major importance with respect to both environmental concerns and the quality of plant products. Cabbage, as other cruciferous vegetables, has high nutritional value and contains specific sulphur compounds glucosinolates that increase its antioxidant activity. Nitrogen and phosphorus are one of the nutrients of major importance in the growth of head cabbage. Lack of these major nutrients causes the plant to be stunted and becomes yellow in appearance thereby decrease yield. An adequate supply of nitrogen is essential for vigorous vegetative growth, head formation and optimum yield of cabbage. However, the response of the crop to nitrogen and phosphorus varies under different soil and agro climatic conditions and thus affecting the optimum level of nitrogen and phosphorus. Achieving and maintaining appropriate levels of soil fertility, especially plant nutrient availability, is of paramount importance in agricultural land to remain capable of sustaining crop production at an acceptable level.

Cabbage has good responsiveness on animal manure application in quantity of $40 \mathrm{t} \mathrm{ha}^{-1}$. Organic fertilization enhances soil biological activity, improves nutrient mobilization and soil structure and increases soil water retention. Systems relying on organic fertilizers as plant nutrient sources have different dynamics of nutrient availability than those using mineral fertilizers. Sustainable crop production with integrated use of mineral and organic fertilizer has proved to be highly beneficial. Several studies have shown the positive effect of combined use of mineral and organic fertilizers in fields that continuously for a few years received only $\mathrm{N}, \mathrm{P}$ and $\mathrm{K}$, without any micronutrient or organic fertilizer $[4,12]$.

\subsubsection{Response of Head Cabbage to Nitrogen Fertilizers}

To produce optimum yields of good quality cabbages, often high amounts of nitrogen fertilizer are applied. The recommended total amounts of nitrogen fertilizer for cabbage are 160 to $260 \mathrm{~kg} \cdot$ ha-1 [9]. In reality, the amount of nitrogen fertilizer used is probably lower as farmers may apply minimum fertilizer than recommended to secure yields. Nitrogen produces reliable and optimal yield and quality of vegetables. It is however, the most difficult element to manage in a fertilization system in order to ensure an adequate, yet not excessive, amount of available nitrogen within the rhizosphere from planting to harvest [25].

Higher levels of nitrogen have often been found to induce optimum yields in Brassica vegetables. Zebarth, et al. (1991) observed a positive yield response up to $500 \mathrm{~kg} \mathrm{ha}^{-1} \mathrm{~N}$, but that percentage nitrogen recovery was lower at the higher rates [39].

Parmar et al. (1999) recorded higher yields in cabbage with increased nitrogen rates. The application of $200 \mathrm{~kg} \cdot \mathrm{ha}-1$ $\mathrm{N}$ produced significantly higher yield over $150 \mathrm{~kg} \cdot \mathrm{ha}-1 \mathrm{~N}$ but at par with $250 \mathrm{~kg} \cdot$ ha- $1 \mathrm{~N}$. This was attributed to the fact that higher nitrogen levels favored the growth of plants with larger leaf area and it was more usefully utilized in head formation [23]. Everaarts and De Moel (1998) also reported increasing uniformity with increasing amounts of nitrogen applied. In cabbage production uniformity of heads is important. Increase in relative core length was observed when nitrogen application rate increased, whereas dry matter content of the heads decreased. This was associated with softer head tissue at higher nitrogen availability, thereby having less physical resistance to stalk elongation [8].

\subsubsection{Response of Head Cabbage to Phosphorus Application}

Among the various factors involved, nutrient supply is an important input for realizing higher cabbage yield and its nutrient content. Results from the previous experiment showed that the response of cabbage is high to nitrogen and moderate to phosphorus application. The importance of nitrogen, phosphorus, potassium and sulphur on the growth and yield of vegetable crops is well established [13]. Phosphorus is also essential nutrient element which helps in the good growth of the roots of vegetable crops. The production increases progressively with the increased amount of $\mathrm{N}$-fertilizer along with phosphorus fertilizer. Application of NPK at the rate of 70,100 and $70 \mathrm{~kg}$ ha-1per hectare respectively increased the number of leaves per plant, size and weight of cabbage head significantly as compared with control treatment. Increased levels of nitrogen with constant doses of phosphorus and potassium increases cabbage yield [14].

\section{Materials and Methods}

\subsection{Description of the Study Sites}

The field trial was conducted during 2017 and 2018 main cropping season at the Bore Agricultural Research Centre which is located in Guji Zones, of Southern Ethiopia. The climatic condition of the area is most humid and sub humid 
moisture condition, which relatively longer growing season. Bore is found at Latitude of $6^{\circ} 26^{\prime} 52^{\prime \prime} \mathrm{N}$ and Longitude $38^{\circ} 561^{\prime} 2$ " E at an altitude of 2736 masl. The annual rainfall ranges from $1400-1800 \mathrm{~mm}$ with a bimodal pattern that extended from April to November. The mean annual minimum and maximum temperature is $10.1^{\circ} \mathrm{C}$ and $20^{\circ} \mathrm{C}$, respectively (Anonymous, 2014). The soil is clay in texture and very strongly acidic with $\mathrm{pH}$ around 4.01-5.33 [12].

\subsection{Description of Experimental Materials}

Head cabbage variety Olsen was used as experimental material. The seeds of this variety were obtained from the open commercial market. The choice of this variety was due to its good adaptability and short vegetative cycle. The seed of variety is normally found in the market at large and it is widely cultivated and consumed in different highland parts of the Zone and best variety for midlands of the area.

\subsection{Description of Experimental Design and Treatments}

The experiment was laid out in a Factorial arrangement of Randomized complete Block Design having two factors i.e., nitrogen and phosphorus with three replications. The treatments include four levels of nitrogen and four levels of phosphorus. There were 16 treatment combinations such as $\mathrm{N}_{1} \mathrm{P}_{1}, \mathrm{~N}_{1} \mathrm{P}_{2}, \mathrm{~N}_{1} \mathrm{P}_{3}$, $\mathrm{N}_{1} \mathrm{P}_{4}, \mathrm{~N}_{2} \mathrm{P}_{1}, \mathrm{~N}_{2} \mathrm{P}_{2}, \mathrm{~N}_{2} \mathrm{P}_{3}, \mathrm{~N}_{2} \mathrm{P}_{4}, \mathrm{~N}_{3} \mathrm{P}_{1}, \mathrm{~N}_{3} \mathrm{P}_{2}, \mathrm{~N}_{3} \mathrm{P}_{3}, \mathrm{~N}_{3} \mathrm{P}_{4}, \mathrm{~N}_{4} \mathrm{P}_{1}$, $\mathrm{N}_{4} \mathrm{P}_{2}, \mathrm{~N}_{4} \mathrm{P}_{3}$ and $\mathrm{N}_{4} \mathrm{P}_{4}$. The treatment details were as (i) Levels of nitrogen (N)-N1: control; N2: $176 \mathrm{~kg}$; N3: $235 \mathrm{~kg}$; N4: $294 \mathrm{~kg}$ ha $^{-1}$; (ii) Levels of phosphorus $\left(\mathrm{P}_{2} \mathrm{O}_{5}\right) \mathrm{P} 1$ : control; P2: $82 \mathrm{~kg}$; P3: $110 \mathrm{~kg}$; P4: $138 \mathrm{~kg} \mathrm{ha}^{-1}$. Forty five days of old seedlings of head cabbage was transplanted using spacing of $50 \mathrm{~cm} * 40 \mathrm{~cm}$ on plots size of $3.0 \mathrm{~m} \mathrm{x} 2.4 \mathrm{~m}$. The distance between the plot and the block is $0.8 \mathrm{~m}^{*} 1.0 \mathrm{~m}$, respectively. The plot consists of six rows and six plant populations per single row, totally 36 plants per plot were employed. The treatments were applied on permanent plots $(3 \mathrm{~m} * 2.4 \mathrm{~m})$ in a randomized complete block design with three replications. Half dose of nitrogen and full dose of phosphorus was applied to the respected treatment as basal dose and the remaining 50\% nitrogen will be given to the treatment at time of head initiation. Urea and NPS fertilizers were used as sources of $\mathrm{N}, \mathrm{P}_{2} \mathrm{O}_{5}$ respectively. Urea $(46 \% \mathrm{~N})$ and DAP $(46 \%$ $\mathrm{P} 2 \mathrm{O} 5+18 \% \mathrm{~N}) \mathrm{TSP}\left(46 \% \mathrm{P}_{2} \mathrm{O}_{5}\right)$ were used as sources of $\mathrm{N}$ and $\mathrm{P}$, respectively.

\subsection{Soil Sampling and Analysis}

Initially a soil sample was collected before land preparation from the depth of $30 \mathrm{~cm}$ from different spots of the experimental field using auger. Then a composite soil sample was made and air dried, crushed and it was passed through $2 \mathrm{~mm}$ sieve in the laboratory for analysis of physicochemical properties of the soil. After harvested the crop, soil samples were also taken from $0-30 \mathrm{~cm}$ soils depth for each replications and composited treatment wise. Then a composite soil was analyzed for determining the soil textural class, $\mathrm{pH}, \mathrm{CEC}$, organic carbon, EC, organic matter, total nitrogen, available $\mathrm{P}$, available $\mathrm{K}$, and Sulphur. The values for each physico-chemical characteristics of the experimental soil were presented in Table 1.

\subsection{Management of the Experiment}

The nursery was prepared by removing plant residues and breaking big soil aggregates. Seedlings of the cabbage were raised in a seed bed. The soil of the seed bed was well ploughed with a spade and prepared in to loose friable dried masses and obtained good tilth that can provide a favorable condition for the vigorous growth of young seedlings. The seeds of the cabbage were sown on raised bed and watered once in a day until the seedlings were emerged and ready for transplanting. In the nursery fertilizer was not applied. Five days before transplanting the seedlings were hardened by reducing irrigation frequency. Then healthy and uniform seedlings were transplanted to a treatment plots after 45 days of sowing. All doses of phosphorus were applied once at time of transplanting and the doses of nitrogen were applied 50\% at time of transplanting and $50 \%$ before head initiation as per treatment dose. Other agronomic practices including weeding, irrigation and cultivation were done uniformly in all plots.

\subsection{Crop Data Collection}

\subsubsection{Phenological Data's}

Days to $50 \%$ head initiation: Days to $50 \%$ head initiation was recorded when half of the plants in a net plot formed heads. Days to $90 \%$ head maturity: It was recorded from the date of transplanting to when $90 \%$ of the heads from the net plot reached maturity. This was determined by the leaf color change, compactness or firmness of the head.

\subsubsection{Growth Parameters Data's}

Number of expanded leaves per plant: The number of leaves per plant was counted and mean of five plants was recorded before the start of head initiation excluding unfolded and dead leaves.

Plant height: The height of the plant was measured by placing a meter scale from ground level to the tip of the outer longest leaf of an individual plant at the time of $90 \%$ days to head maturity. Thus, mean of five selected plants of a single plot was recorded and expressed in centimeter $(\mathrm{cm})$.

\subsubsection{Yield and Yield Components Data's}

Average fresh weight of untrimmed head per plant: The fresh weight of heads with unfolded leaves per plant was found from the average weight of selected five plants and expressed in gram (g) when yield data was taken.

Average fresh weight of trimmed head per plant: The fresh weight of marketable head per plant was found from the average weight of five plants and was expressed in gram $(\mathrm{g})$ when yield data was taken.

Diameter of head: Five heads were taken randomly. Then sectioning of head was done horizontally with a sharp knife at the middle portion. The diameter of head was measured as the horizontal distance from one side to another side of the selected head and was expressed in centimeter $(\mathrm{cm})$.

Height of head: Head height $(\mathrm{cm})$ was obtained from five representative plants per net plot area and measured by 
cutting vertically using a ruler at the time of harvesting.

Gross head yield with wrapper: Heads with unfolded leaves of all the plants within a net plot area (harvested area 2 $\mathrm{m} \times 2.8 \mathrm{~m}$ ) were weighed and converted to tons per hectare.

Marketable yield without wrapper per plot: Heads without unfolded leaves of all the plants within a net plot area (harvested area $2 \mathrm{~m} \times 2.8 \mathrm{~m}$ ) were weighed and converted to tons per hectare.

\subsection{Partial Budget Analysis}

Variable cost of $\mathrm{N}$ and $\mathrm{P}$ fertilizer was largely used for partial budget analysis. Price fluctuations during the production season were considered. Marginal Rate of Return, which refers to net income obtained by incurring a unit cost of fertilizer, was calculated by dividing the net increase in yield of cabbage due to the application of each rate to the total cost of $\mathrm{N}$ and $\mathrm{P}$ fertilizer applied at each rate. This enables to identify the most economic rate and source of $\mathrm{N}$ and $\mathrm{P}$ fertilizer for cabbage production [6]. This was achieved by dividing the total variable cost by the net benefit multiplied by 100 .

$$
\operatorname{MRR}(\%)=\frac{\text { Marginal benefit }}{\text { Marginal cost }} \times 100
$$

\subsection{Statistical Data Analysis}

Analysis of variance procedures was used on every measured parameter to determine the significance of differences between means of treatments using the SAS 9.1.3 systems software for each parameters, and separated by the least significant difference (LSD) using the statistical package. Yield and yield related data was statistically analyzed using the Proc Glm function of SAS and means were compared using LSD at a probability level of 5\% [27].

\section{Results and Discussions}

\subsection{Soil Physicochemical Properties}

\subsubsection{Soil Physicochemical Properties of Site Before Planting}

The analytical results of soil prior to planting indicated that the textural class of the soil was clay which is comfortable for production (Table 1). Accumulation of different organic materials during previous growing seasons might have resulted in high pre-plant organic carbon content $(3.02 \%)$, which might have contributed to the high level of total $\mathrm{N}(0.30 \%)$, low level of available phosphorus (4.52 $\mathrm{ppm})$, high level of exchangeable potassium $(262.25 \mathrm{mg} / \mathrm{kg}$ (ppm)), and medium level of CEC (22.11 Meq/100g) in the soil. Tekalign et al. (1991) and Berhanu (1980) rated 0.12$0.25 \%$ total $\mathrm{N}$ as high, $>3 \%$ OC as high and Olsen et al. (1954) rated available phosphorus range 5-10 ppm as medium. While Jones, J. Benton (2003) rated available K range 141-300 as high and CEC of. Hazelton and Murphy

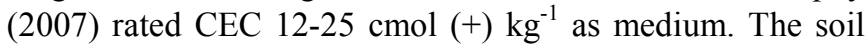
$\mathrm{pH}$ was also very strongly acidic with a value of $4.3(\mathrm{pH}-$ $\mathrm{H} 2 \mathrm{O}$ ). Generally, the soil physical and chemical analysis prior to planting indicated that the soils of the experimental fields are potentially productive from the perspectives of chemical properties of soils for cabbage growth except soil acidity of the soil since the ideal soil $\mathrm{pH}$ ranges from 5.5 to 6.5 and it should not be allowed to drop below 4.5. Therefore for better fertilizer response the physical nature of the soil should be improved through composted manure and lime to improve moisture retention and raise soil $\mathrm{pH}$.

Table 1. Soil Physiochemical properties of experimental site before planting.

\begin{tabular}{lll}
\hline Soil characters & Values & Examination standards \\
\hline $\mathrm{pH}($ by $1: 2.5$ soil water ratio) & 4.30 & ES ISO 10390: 2014 (1:2.5) \\
Total nitrogen $(\%)$ & 0.30 & ES ISO 11261: 2015 (Kjeldahl Method) \\
Organic carbon $(\%)$ & 3.02 & Walkley and Black Method \\
Available phosphorous $(\mathrm{mg} / \mathrm{kg}(\mathrm{ppm}))$ & 4.52 & ES ISO 11261: 2015 (Olsens Method) \\
Cation exchange capacity $(\mathrm{Meq} / 100 \mathrm{~g})$ & 22.11 & Ammonium Acetate Method \\
Available potassium $(\mathrm{mg} / \mathrm{kg}(\mathrm{ppm}))$ & 262.25 & Ammonium Acetate Method \\
Available sulfur $(\mathrm{mg} / \mathrm{kg}(\mathrm{ppm}))$ & 31.19 & Turbidometreic \\
Soil texture: & & Bouyoucos Hydrometer Method \\
Sand & 28 & \\
Silt & 43 & \\
Clay & 31 & \\
Class & Clay & \\
\hline
\end{tabular}

Source: Tekalign et al. (1991), Berhanu (1980), Olsen et al. (1954), Jones, J. Benton (2003) and Hazelton and Murphy (2007).

\subsubsection{Soil Physicochemical Properties After Crop Harvest}

The analysis of the experimental soil after harvest for $\mathrm{pH}$, available phosphorus, total nitrogen, sulfur, available potassium, organic carbon, cation exchange capacity and texture is indicated in Table 2. The result revealed that available phosphorus organic carbon, total nitrogen and CEC were increased while available sulfur and available potassium decreased after the application of nitrogen and phosphorus to the experimental plot. However, the range of $\mathrm{pH}$ change was only from 4.11 to 5.35 with treatment employed (Table 2) which could be due to the inactivation of nitrogenous fertilizer we used which correspondingly increased the level of soil $\mathrm{pH}$.

The result obtained from composited soil analysis showed that the treatments with $235 \mathrm{~kg} \mathrm{~N} \mathrm{ha}^{-1}$ and $138 \mathrm{~kg} \mathrm{ha}^{-1}$ of Phosphorus rate gave an increase of $5.35 \% \mathrm{pH}, 3.11 \%$ OC 
and $0.31 \%$ of total nitrogen. However $294 \mathrm{~kg} \mathrm{~N} \mathrm{ha}^{-1}$ and 138 $\mathrm{kg} \mathrm{ha}^{-1}$ of Phosphorus rate gave an increased available $\mathrm{S}$ of $22.05 \mathrm{mg} / \mathrm{kg}$ of soil and application of $138 \mathrm{~kg} \mathrm{ha}^{-1}$ of phosphorus gave $30.62 \mathrm{Meq} / 100 \mathrm{~g}$ CEC. Similarly, the combined application of the highest rate of $235 \mathrm{~kg} \mathrm{ha}^{-1}$ and $138 \mathrm{~kg} \mathrm{ha}^{-1}$ phosphorus increased the $\mathrm{P}_{2} \mathrm{O}_{5}$ level from 4.52 to $16.26 \mathrm{mg} \mathrm{kg}^{-1}$ after harvest. As the rate of nitrogen and phosphorus application increases, the soil characteristic parameters were increased with increase in nitrogen and phosphorus concentration. Maximum $\mathrm{pH}$ (5.35) was recovered, when $235 \mathrm{~kg} \mathrm{ha}^{-1}$ and $138 \mathrm{~kg} \mathrm{ha}^{-1}$ phosphorus applied with relatively higher rate of phosphorous. This increase in $\mathrm{pH}$ of the soil increased the availability of cations under acid soils in the study area.

Table 2. Soil Physiochemical properties of experimental site after crop harvest.

\begin{tabular}{|c|c|c|c|c|c|c|c|c|c|c|c|c|c|c|}
\hline \multicolumn{2}{|l|}{ Treatments } & \multirow{2}{*}{ - PH } & \multirow{2}{*}{$P(\mathrm{mg} / \mathrm{kg})$} & \multirow{2}{*}{$\mathrm{S}(\mathrm{mg} / \mathrm{kg})$} & \multirow{2}{*}{ K (mg/kg) } & \multirow{2}{*}{$\begin{array}{l}\text { CEC } \\
(\text { Meq/100g) }\end{array}$} & \multirow{2}{*}{ OC (\%) } & \multirow{2}{*}{$\begin{array}{l}\text { OM } \\
(\%) \\
\end{array}$} & \multirow{2}{*}{$\begin{array}{l}\text { TN } \\
(\%)\end{array}$} & \multirow{2}{*}{$C: \mathbf{N}$} & \multicolumn{3}{|c|}{ Texture } & \multirow{2}{*}{ - Class } \\
\hline N rate $\left(\mathrm{kg} \mathrm{ha}^{-1}\right)$ & P rate $\left(\mathrm{kg} \mathrm{ha}^{-1}\right)$ & & & & & & & & & & Sand & Clay & Silt & \\
\hline 0 & 0 & 4.3 & 13.38 & 10.34 & 105 & 24.32 & 2.87 & 4.94 & 0.3 & 9.52 & 30 & 44 & 26 & Clay \\
\hline 0 & 82 & 4.58 & 14.99 & 8.06 & 106 & 23.88 & 3.07 & 5.29 & 0.31 & 9.91 & 28 & 44 & 28 & Clay \\
\hline 0 & 110 & 4.48 & 9.81 & 20.16 & 136.5 & 21.33 & 3.11 & 5.37 & 0.3 & 10.24 & 26 & 42 & 32 & Clay \\
\hline 0 & 138 & 4.33 & 6.93 & 14.68 & 74.2 & 30.62 & 3.03 & 5.22 & 0.3 & 10.17 & 26 & 46 & 28 & Clay \\
\hline 176 & 0 & 4.13 & 12.75 & 13.13 & 105 & 20.44 & 2.89 & 4.99 & 0.3 & 9.61 & 26 & 46 & 28 & Clay \\
\hline 176 & 82 & 4.11 & 12.02 & 15.16 & 106 & 28.66 & 3.06 & 5.27 & 0.31 & 9.77 & 26 & 46 & 28 & Clay \\
\hline 176 & 138 & 5.29 & 12.66 & 16.11 & 127.2 & 21.43 & 2.87 & 4.94 & 0.3 & 9.58 & 30 & 42 & 28 & Clay \\
\hline 235 & 0 & 5.15 & 16.53 & 20.16 & 99.75 & 20.18 & 2.92 & 5.03 & 0.31 & 9.51 & 30 & 44 & 26 & Clay \\
\hline 235 & 82 & 5.26 & 14.29 & 14.87 & 104 & 21.13 & 2.89 & 4.98 & 0.3 & 9.61 & 30 & 44 & 26 & Clay \\
\hline 235 & 110 & 4.86 & 8.76 & 12.65 & 126 & 18.77 & 2.8 & 4.82 & 0.3 & 9.8 & 28 & 42 & 30 & Clay \\
\hline 235 & 138 & 5.35 & 16.26 & 14.68 & 100.7 & 17.79 & 3.11 & 4.87 & 0.31 & 9.45 & 30 & 42 & 28 & Clay \\
\hline 294 & 0 & 5.07 & 9.48 & 15.16 & 111.3 & 24.04 & 2.82 & 5.36 & 0.30 & 10.2 & 30 & 44 & 26 & Clay \\
\hline 294 & 82 & 4.98 & 12.87 & 12.77 & 100.7 & 19.29 & 2.78 & 4.8 & 0.31 & 8.86 & 30 & 44 & 26 & Clay \\
\hline 294 & 110 & 5.33 & 11.07 & 11.7 & 131.25 & 20.03 & 2.84 & 4.89 & 0.3 & 9.59 & 30 & 44 & 26 & Clay \\
\hline
\end{tabular}

\subsection{Phenological Parameters of Head Cabbage}

\subsubsection{Days to 50\% Head Initiation}

The analysis of variance indicated that interaction effects of Nitrogen and Phosphorus had significant $(\mathrm{p}<0.05)$ effect on days to $50 \%$ heading (Table 3 ).

Table 3. Interaction effect of $N$ and $P$ on days to $50 \%$ head initiation of head cabbage.

\begin{tabular}{lllll}
\hline $\begin{array}{l}\text { Phosphorus (kg } \\
\left.\text { ha }^{-1}\right)\end{array}$ & \multicolumn{4}{l}{ Nitrogen $\left(\mathbf{k g ~ h a}^{\mathbf{- 1}}\right)$} \\
\cline { 2 - 5 } & $\mathbf{0}$ & $\mathbf{1 7 6}$ & $\mathbf{2 3 5}$ & $\mathbf{2 9 4}$ \\
\hline 0 & $64.33^{\mathrm{i}}$ & $70.66^{\mathrm{f}}$ & $72.00^{\mathrm{ef}}$ & $71.33^{\mathrm{f}}$ \\
82 & $65.33^{\mathrm{hi}}$ & $80.66^{\mathrm{b}}$ & $79.66^{\mathrm{bc}}$ & $78.33^{\mathrm{c}}$ \\
110 & $67.00^{\mathrm{gh}}$ & $72.33^{\text {ef }}$ & $79.66^{\mathrm{bc}}$ & $78.66^{\mathrm{bc}}$ \\
138 & $68.00^{\mathrm{g}}$ & $73.66^{\mathrm{e}}$ & $76.00^{\mathrm{d}}$ & $90.00^{\mathrm{a}}$ \\
$\mathrm{LSD}(0.05) \mathrm{N}^{*} \mathrm{P}=2.14 ; \mathrm{CV}(\%)=1.74$ & & \\
\hline
\end{tabular}

Means in columns and rows followed by the same letter(s) are not significantly different at $5 \%$ level of significance. LSD $(0.01)=$ Least Significant Difference at $1 \%$ level; and CV $(\%)=$ coefficient of variation in percent.

The shortest head initiation (64.33 days) was obtained in control treatment where the longest (90 days) duration was attained in $294 \mathrm{~kg} \mathrm{ha}^{-1}$ Nitrogen and $138 \mathrm{~kg} \mathrm{ha}^{-1}$ phosphorus treatment (Table 3 ). The control treatment resulted in early finish of heading before attaining of fully required physiological maturity and matured early as compared to those higher doses. This might be due to lower $\mathrm{N}$ and $\mathrm{P}$ rates not enough to enhance the development of the crop and hastening head formation and maturity.

\subsubsection{Days to 90\% Maturity}

The analysis of variance indicated that interaction effects of Nitrogen and Phosphorus had significant $(p<0.05)$ effect on days to maturity (Table 4). Plots treated with lowest (control) combination rates took shorter period to mature which might be because lower rate of Nitrogen and Phosphorus not enough to enhance the development of the crop and hastening head formation and maturity. While plots treated with maximum $294 \mathrm{~kg} \mathrm{ha}^{-1}$ Nitrogen and $138 \mathrm{~kg} \mathrm{ha}^{-1}$ phosphorus combination rates took longer (140) days to mature. The increase in days to maturity due to nutrient application might be related to its role in stimulation of plant growth by the assimilation of major elements and changes in protein synthesis and finally related to growth and production of the crop.

Table 4. Interaction effect of $N$ and $P$ on days to maturity of head cabbage.

\begin{tabular}{lllll}
\hline $\begin{array}{l}\text { Phosphorus } \\
\left(\mathbf{k g ~ h a}^{-1}\right)\end{array}$ & \multicolumn{4}{l}{ Nitrogen $\left(\mathbf{k g ~ h a}{ }^{-1}\right)$} \\
\cline { 2 - 5 } 0 & $\mathbf{0}$ & $\mathbf{1 7 6}$ & $\mathbf{2 3 5}$ & $\mathbf{2 9 4}$ \\
\hline 02 & $109.66^{\mathrm{j}}$ & $117.00^{\mathrm{h}}$ & $118.00^{\mathrm{h}}$ & $125.00^{\mathrm{f}}$ \\
110 & $108.00^{\mathrm{j}}$ & $120.00^{\mathrm{g}}$ & $132.00^{\mathrm{d}}$ & $132.66^{\mathrm{cd}}$ \\
138 & $108.00^{\mathrm{j}}$ & $127.00^{\mathrm{e}}$ & $135.33^{\mathrm{b}}$ & $139.00^{\mathrm{a}}$ \\
$\mathrm{LSD}(0.05) \mathrm{N}^{*} \mathrm{P}=1.71 ; \mathrm{CV}(\%)=0.82$ & $139.66^{\mathrm{a}}$ & $140.33^{\mathrm{a}}$ \\
\hline
\end{tabular}

Means in columns and rows followed by the same letter(s) are not significantly different at $5 \%$ level of significance. LSD $(0.01)=$ Least Significant Difference at $1 \%$ level; and CV $(\%)=$ coefficient of variation in percent.

\subsection{Growth Parameters of Head Cabbage}

\subsubsection{Number of Expanded Leaves}

The combined effect of nitrogen and phosphorus was found significant $(\mathrm{P}<0.05)$ for the characters of number of expanded leaves and Plant height of head cabbage. 
Combined application of $294 \mathrm{~kg}$ nitrogen and $138 \mathrm{~kg}$ phosphorus ha ${ }^{-1}$ (N4P4) recorded maximum number of outer leaves (8.33) per plant, while the lowest (5.00) number was recorded from the control (Table 5). The higher nutrient rates, relative to lower rates, increased leaf count regardless of the sampling date. Leaf count increased from plots received of maximum plant nutrient for transplanted treatments, respectively as nitrogen was increased from 176 to $294 \mathrm{~kg} \mathrm{ha}^{-1}$. The tendency for the leaf count to increase in response to increasing nitrogen application is in agreement with the results of [20]. They observed increases in tomato leaf count as nitrogen was increased during both years of their study.

\subsubsection{Plant Height}

The mean data revealed that plant height was significantly $(\mathrm{P}<0.05)$ influenced by the combination of Nitrogen and Phosphorus nutrients and it tended to increase with the application of higher amount of nutrients. Plant height is one of the important growth contributing characters for cabbage plant. It depends on several factors like genetic makeup, nutrient availability, climate, soil, etc. Among those nutrient availability is one of the important factors for desirable plant height.

The maximum plant height $(26.4 \mathrm{~cm})$ was recorded for the treatment T3P4 $\left(235+138 \mathrm{kag} \mathrm{ha}^{-1}\right)$, while the lowest (16.9 $\mathrm{cm}$ ) plant height was recorded from the T1P1 (control) treatment (Table 4). [24] Noted significant difference in plant height of head cabbage due to different source of nutrients. The increments of plant height in broccoli by the application of $240 \mathrm{~kg} \mathrm{~N}, 100 \mathrm{~kg} \mathrm{P}$ and $80 \mathrm{~kg} \mathrm{ha}^{-1}$ also reported by [21]. Nitrogen and Phosphorus were the mineral nutrient that boosts plant growth and development [22].

Table 5. Mean Interaction effects of $\mathrm{N}$ and $\mathrm{P}_{2} \mathrm{O}_{5}$ fertilizers on plant height and expanded true leaves of head cabbage at Bore during 2018 and 2019 cropping season.

\begin{tabular}{lll}
\hline Treatments & ETLV (no) & PH (cm) \\
\hline N1P1 & $5.00^{\text {d }}$ & $16.9^{\text {de }}$ \\
N1P2 & $6.66^{\text {abcd }}$ & $19.10^{\text {cde }}$ \\
N1P3 & $7.00^{\text {abcd }}$ & $17.9^{\text {cde }}$ \\
N1P4 & $7.33^{\text {abc }}$ & $21.06^{\text {abcde }}$ \\
N2P1 & $8.00^{\text {ab }}$ & $17.8^{\text {cde }}$ \\
N2P2 & $5.66^{\text {cd }}$ & $19.5^{\text {cde }}$ \\
N2P3 & $6.66^{\text {abcd }}$ & $20.9^{\text {abcde }}$ \\
N2P4 & $6.00^{\text {bcd }}$ & $19.6^{\text {cde }}$ \\
N3P1 & $7.33^{\text {abc }}$ & $17.3^{\text {cde }}$ \\
N3P2 & $7.66^{\text {abc }}$ & $20.7^{\text {abcde }}$ \\
N3P3 & $7.00^{\text {abcd }}$ & $18.9^{\text {cde }}$ \\
N3P4 & $6.66^{\text {abcd }}$ & $26.4^{\mathrm{a}}$ \\
N4P1 & $6.33^{\text {abcd }}$ & $22.9^{\text {abc }}$ \\
N4P2 & $7.00^{\text {abcd }}$ & $25.7^{\text {ab }}$ \\
N4P3 & $7.66^{\text {abc }}$ & $20.5^{\text {bcde }}$ \\
N4P4 & $8.33^{\mathrm{a}}$ & $22.5^{\text {abcd }}$ \\
Mean & 6.95 & 20.42 \\
LSD $(5 \%)$ & 2.25 & 5.78 \\
CV $\%$ \% & 19.45 & 17.01 \\
\hline
\end{tabular}

Means within the same column followed by the same letter (s) are not significantly different at $5 \%$ level of significance; $\mathrm{PH}=$ Plant height $(\mathrm{cm})$, $E T L V=$ No of expanded true leaves, LSD = Least Significant difference; NS $=$ Not significant $\mathrm{CV}=$ Coefficient of Variation.

\subsection{Yield Components and Yield of Head Cabbage}

\subsubsection{Yield Related Components}

\section{(i). Head Diameter and Head Height}

As shown in Table 6. Effect of $\mathrm{N}$ and $\mathrm{P}$ levels on growth and yield parameters of cabbage (Brassica oleracea L.) under Bore soil conditions was significantly different $(\mathrm{P}<0.05)$. Diameter of head is an important yield contributing character of cabbage. Nutrient levels markedly influenced the diameter, height, head mass and yield of head cabbage (Table $6)$. The maximum average diameter $(25.44 \mathrm{~cm})$ and average height $(27.33 \mathrm{~cm})$ was recorded in treatment receiving $235 \mathrm{~kg}$ $\mathrm{N}$ and $82 \mathrm{~kg} \mathrm{P} \mathrm{ha}{ }^{-1}$. The minimum diameter $(10.31 \mathrm{~cm})$ and minimum $(12.33 \mathrm{~cm})$ height was noted by control treatment. It was observed that fertilizer application at different levels result a remarkable change in height and diameter of the head. This result was corroborated with the findings of [28]. Din et al. reported significantly higher diameter of head cabbage by the application of 120-90-80 NPK harespectively [7]. That means application of higher nutrient to some level induced maximum diameter and height of cabbage. There was a strong positive correlation between diameter, height and yield without wrapper.

Table 6. Combined Mean Interaction effect of $\mathrm{N}$ and $\mathrm{P}_{2} \mathrm{O}_{5}$ fertilizers on head height, diameter of head, untrimmed head mass, trimmed head mass, of Head cabbage at Bore during 2018 and 2019 cropping season.

\begin{tabular}{|c|c|c|c|c|}
\hline \multirow{2}{*}{ Treatments } & \multicolumn{4}{|c|}{ Yield related parameters } \\
\hline & HH (cm) & DH (cm) & UTHM (gm) & THM (gm) \\
\hline N1P1 & $12.33^{j}$ & $10.31^{\mathrm{k}}$ & $1120.67^{j}$ & $952.57^{j}$ \\
\hline N1P2 & $16^{\mathrm{i}}$ & $14.80^{\mathrm{j}}$ & $1403.67^{\mathrm{i}}$ & $1193.12^{\mathrm{i}}$ \\
\hline N1P3 & $18^{\mathrm{h}}$ & $16.10^{\mathrm{i}}$ & $1435.0^{\mathrm{i}}$ & $1219.75^{\mathrm{i}}$ \\
\hline N1P4 & $18^{\mathrm{h}}$ & $16.86^{\mathrm{i}}$ & $1487.67^{\mathrm{i}}$ & $1264.52 \mathrm{i}$ \\
\hline N2P1 & $19.33^{\mathrm{g}}$ & $18.23^{\mathrm{h}}$ & $1655.00^{\mathrm{h}}$ & $1406.75^{\mathrm{h}}$ \\
\hline $\mathrm{N} 2 \mathrm{P} 2$ & $22^{\mathrm{de}}$ & $19.98^{\mathrm{ef}}$ & $1947.33^{\mathrm{efg}}$ & $1655.23^{\mathrm{efg}}$ \\
\hline $\mathrm{N} 2 \mathrm{P} 3$ & $23.33^{\mathrm{c}}$ & $22.16^{\mathrm{b}}$ & $2005.00^{\mathrm{def}}$ & $1704.25^{\mathrm{def}}$ \\
\hline $\mathrm{N} 2 \mathrm{P} 4$ & $24.66^{\mathrm{b}}$ & $21.72^{\text {bcd }}$ & $2113.33^{\mathrm{bc}}$ & $1796.33^{\mathrm{bc}}$ \\
\hline N3P1 & $19.33^{\mathrm{g}}$ & $18.56^{\mathrm{gh}}$ & $1844.33^{\mathrm{g}}$ & $1567.68^{g}$ \\
\hline N3P2 & $27.33^{\mathrm{a}}$ & $25.44^{\mathrm{a}}$ & $2356.67^{\mathrm{a}}$ & $2003.17^{\mathrm{a}}$ \\
\hline N3P3 & $24.33^{\mathrm{b}}$ & $20.99^{\text {cde }}$ & $2133.33^{b}$ & $1813.33^{\mathrm{b}}$ \\
\hline N3P4 & $24.33^{\mathrm{b}}$ & $22.04^{\mathrm{bc}}$ & $2066.67^{\mathrm{bcd}}$ & $1756.67^{\mathrm{bcd}}$ \\
\hline N4P1 & $20.33^{\mathrm{f}}$ & $19.13^{\text {fgh }}$ & $1906.67^{\mathrm{fg}}$ & $1620.67^{\mathrm{fg}}$ \\
\hline N4P2 & $2.33^{\mathrm{de}}$ & $20.82^{\text {de }}$ & $2002.00^{\mathrm{def}}$ & $1701.7^{\text {def }}$ \\
\hline N4P3 & $22.66^{\mathrm{cd}}$ & $20.14^{\mathrm{ef}}$ & $2017.00^{\text {cde }}$ & $1714.45^{\mathrm{cde}}$ \\
\hline N4P4 & $21.66^{\mathrm{e}}$ & $19.66^{\mathrm{fg}}$ & $1929.33^{\mathrm{efg}}$ & $1639.93^{\text {efg }}$ \\
\hline Mean & 21.00 & 19.18 & 1838.98 & 1563 \\
\hline $\operatorname{LSD}(5 \%)$ & 0.92 & 1.12 & 103.46 & 87.94 \\
\hline CV (\%) & 2.66 & 3.52 & 3.38 & 3.38 \\
\hline
\end{tabular}

Means within the same column followed by the same letter (s) are not significantly different at $5 \%$ level of significance; $\mathrm{HH}=$ head height, $\mathrm{DH}=$ diameter of head, UTHM=untrimmed head mass, THM=trimmed head mass, LSD = Least Significant difference; NS = Not significant; $\mathrm{CV}=$ Coefficient of Variation.

\section{(ii). Untrimmed and Trimmed Weight of Head Cabbage}

The untrimmed and trimmed weight of head cabbage was highly significantly $(\mathrm{P}<0.05)$ influenced by the main effect of the application of different levels of nitrogen and phosphorus and their interaction (Table 6). Combined application of 235 $\mathrm{kg} \mathrm{N} \mathrm{ha}^{-1}$ with the $82 \mathrm{~kg} \mathrm{P} \mathrm{ha}^{-1}$ produced the highest $(2356.67$ g) untrimmed head weight of cabbage followed by second 
maximum $(2133.33 \mathrm{~g})$ untrimmed head weight with the rate of $235 \mathrm{~kg} \mathrm{~N}^{-1}$ with the $110 \mathrm{~kg} \mathrm{P} \mathrm{Pa}^{-1}$ while the least $(1120.67 \mathrm{~g})$ untrimmed head weight was recorded for the control treatment (Table 6). The increase in head weight might be attributed to the beneficial effect of nutrient on stimulating the meristimic activity for producing more tissues and organs, in addition to its vital contribution in several biochemical processes in the plant, related to growth and yield development [19].

\subsubsection{Yield Components}

\section{(i). Yield with Wrapper}

From the present research it was observed yield with and without wrapper varied significantly $(\mathrm{P}<0.05)$ among the treatments tested due to application of nutrients (Table 7).

The highest head yield with wrapper $\left(73.83 \mathrm{t} \mathrm{ha}^{-1}\right)$ was found from the treatment combination of N3P2 (dose of 235 $\mathrm{kg} \mathrm{N} \mathrm{ha}{ }^{-1}+82 \mathrm{~kg} \mathrm{P} \mathrm{ha}^{-1}$ ) followed by $1813.33 \mathrm{t} \mathrm{ha}^{-1}$ with dose of $235 \mathrm{~kg} \mathrm{~N} \mathrm{ha}^{-1}+110 \mathrm{~kg} \mathrm{P} \mathrm{ha}^{-1}$ at $5 \%$ level of significance, while the lowest yield with wrapper (29.59 $\mathrm{t} \mathrm{ha}^{-1}$ ) was recorded in the treatment T1P1 (zero application). From the above result it was observed that combination of fertilizers with recommended rate of $\mathrm{NP}_{2} \mathrm{O}_{5}$ fertilizers is the best for production of highest head yield with wrapper.

\section{(ii). Yield Without Wrapper}

Similar to wrapper yield, the yields of cabbage without wrapper was significantly $(\mathrm{P}<0.05)$ affected both by the main and interaction effect of nitrogen and phosphorus (Table 6). The combined effect of nitrogen and phosphorus was found significant for most of the characters of head cabbage. Combined application of $235 \mathrm{~kg}$ nitrogen and $82 \mathrm{~kg}$ phosphorus $\mathrm{ha}^{-1}$ (N3P2) recorded maximum (69.00 t) head yield without wrapper ha ${ }^{-1}$ and the lowest $\left(27.66 \mathrm{t} \mathrm{ha}^{-1}\right)$ was recorded by control treatment. Yield without wrapper or marketable head yield was reduced due to the application of nutrients above $235 \mathrm{~kg} \mathrm{~N}$ and $82 \mathrm{~kg} \mathrm{P} \mathrm{ha}^{-1}$. It might be due to increase in all the above mention parameters that attribute to increase the final yield $\mathrm{ha}^{-1}$ which is due to more vegetative growth, development, photosynthesis, dry matter synthesis and translocation to storage organ. It might be also due to the optimum accumulation of $\mathrm{N}$ and translocation of micronutrient such as boron and thus yield from the crops get increases. Similar results were found by $[32,28]$. Din et al. also reported that maximum head yield was recorded in treatment receiving $120 \mathrm{~kg} \mathrm{~N}, 90 \mathrm{~kg} \mathrm{P}$ and $80 \mathrm{~kg} \mathrm{~K} / \mathrm{ha} \mathrm{[7].}$

For the current experiment higher yields at higher nitrogen doses could be attributed to great head height, diameter and mass obtained at higher nitrogen and phosphorus doses. Westerveld et al. reported increases in head width (diameter) and height as nitrogen application was increased up to 255 $\mathrm{kg} \cdot \mathrm{ha}^{-1}$. Generally excessive application cannot increase economic yield rather plants used for luxury consumption [37]. Solomon et al. reported that Application of optimum N and FYM not only increased crop productivity, but also improved quality of the product as expressed in terms of its highest marketable to unmarketable yield ratio, mainly due to reduced cracking and improved size, particularly for the reduced or balanced application of fertilizer [30].

Table 7. Mean Interaction effects of $\mathrm{N}$ and $\mathrm{P}_{2} \mathrm{O}_{5}$ fertilizers on head height, diameter of head, untrimmed head mass, trimmed head mass, yield with wrapper and without wrapper of Head cabbage at Bore during 2018 and 2019 cropping season.

\begin{tabular}{lll}
\hline Treatments & YWR $\left(\mathbf{t ~ h a} \mathbf{~ h}^{-1}\right)$ & YWOR $\left(\mathbf{t ~ h a} \mathbf{~}^{-1}\right)$ \\
\hline N1P1 & $29.59^{\mathrm{n}}$ & $27.66^{\mathrm{n}}$ \\
N1P2 & $32.88^{\mathrm{m}}$ & $30.73^{\mathrm{m}}$ \\
N1P3 & $36.13^{\mathrm{l}}$ & $33.76^{1}$ \\
N1P4 & $38.52^{\mathrm{k}}$ & $36.00^{\mathrm{k}}$ \\
N2P1 & $42.72^{\mathrm{j}}$ & $39.92^{\mathrm{j}}$ \\
N2P2 & $51.58^{\mathrm{h}}$ & $48.21^{\mathrm{h}}$ \\
N2P3 & $59.49^{\mathrm{f}}$ & $55.60^{\mathrm{f}}$ \\
N2P4 & $66.37^{\mathrm{c}}$ & $62.03^{\mathrm{c}}$ \\
N3P1 & $43.34^{\mathrm{j}}$ & $40.51^{\mathrm{j}}$ \\
N3P2 & $73.83^{\mathrm{a}}$ & $69.00^{\mathrm{a}}$ \\
N3P3 & $71.69^{\mathrm{b}}$ & $67.00^{\mathrm{b}}$ \\
N3P4 & $63.20^{\mathrm{d}}$ & $59.06^{\mathrm{d}}$ \\
N4P1 & $48.00^{\mathrm{i}}$ & $44.86^{\mathrm{i}}$ \\
N4P2 & $60.81^{\mathrm{e}}$ & $56.83^{\mathrm{e}}$ \\
N4P3 & $53.78^{\mathrm{g}}$ & $50.27^{\mathrm{g}}$ \\
N4P4 & $51.36^{\mathrm{h}}$ & $48.00^{\mathrm{h}}$ \\
Mean & 51.45 & 48.09 \\
LSD (5\%) & 1.16 & 1.09 \\
CV (\%) & 1.36 & 1.36 \\
\hline
\end{tabular}

Means within the same column followed by the same letter (s) are not significantly different at 5\% level of significance; YWR=yield with wrapper and $\mathrm{YWOR}=$ without wrapper, $\mathrm{LSD}=$ Least Significant difference; NS = Not significant; $\mathrm{CV}=$ Coefficient of Variation.

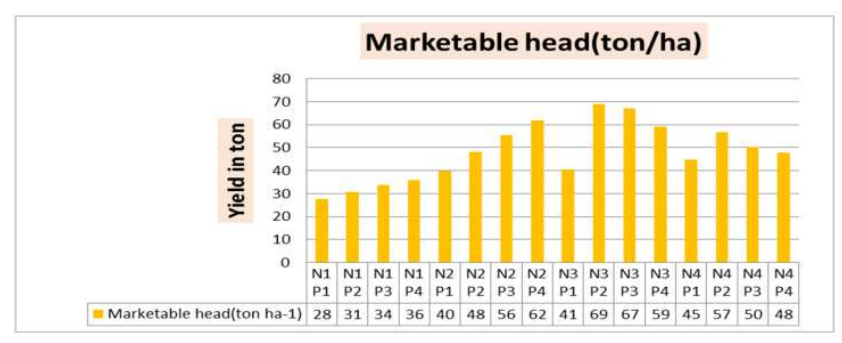

Figure 1. Effects of $\mathrm{N}$ and $\mathrm{P}_{2} \mathrm{O}_{5}$ fertilizers on head yield.

\subsection{Economic Analysis}

The idea of an economic optimum is based on the wisely appealing notion of doing something only as long as it pays to do it. This marginal principle basically suggests that the producer should apply fertilizer only as long as the cost is no more than the additional benefit from increased crop yield. In birr terms, the end result is that the producer will maximize net returns (revenue minus cost). To illustrate this point, we have performed a simple cost-benefit analysis with the results given in Table 8 . Partial budget analysis was done based on the view of CIMMYT Economics Program recommendations, which stated that the application of nutrients with the marginal rate of return above the minimum level $(100 \%)$ is economical. The result indicated that the application of nitrogen and phosphorus on Olsen cabbage variety had gave promoting benefit over the control treatment [6]. 
In this study, the costs of Nitrogen, Phosphorus fertilizer and labor cost for fertilizer application and weeding varied, while other costs were constant for each treatment. In order to recommend the present result for end users, it is necessary to estimate the minimum rate of return acceptable to farmers in the recommendation domain. Based on partial budget analysis, the net benefit accrued from the experiment ranged from nitrogen application alone is 139127 to 153833 birr per hectare compared with non-application of nutrients which is 98376 birr per hectare. For the phosphorus treatments alone net benefit ranged from 107834 to 125654 birr per hectare benefit. This is an indication of the level of profitability of the fertilizer application treatments.

The marginal rate of returns, which determines the acceptability of any treatments shows that treatments that received $235 \mathrm{~kg} \mathrm{~N}^{-1}$ in combination with $82 \mathrm{~kg} \mathrm{P}^{-1}$ yielded best result 434.98 marginal revenue. However, the marginal rate of returns for the Nitrogen fertilizer alone was higher than those for the phosphorus fertilizer. All in all the highest net benefit 241456 birr was obtained from treatment combination of $235 \mathrm{~kg} \mathrm{~N}^{-1}$ with $82 \mathrm{~kg} \mathrm{ha}^{-1}$ of $\mathrm{P}$ with a marginal rate of return 434.98 but the lowest net benefit 98376 birr was obtained from the treatment non-application of nutrients only in two growing season. This means that for every 1.00 birr invested for $235 \mathrm{~kg} \mathrm{~N} \mathrm{ha}^{-1}$ with $82 \mathrm{~kg} \mathrm{ha}^{-1}$ of $\mathrm{P}$ input and its application in the field, farmers can expect to recover the 1.00 birr and obtain an additional 434.98 birr. In general, the negative value of MRR percentage indicated that the loss on investment, whereas, the positive number indicated that a profit or gain on combined use of nitrogen and phosphorus fertilizer to produce the output. Therefore, the economic rates for producers with low cost of production and higher benefits were the treatment combination of $235 \mathrm{~kg}$ $\mathrm{N}$ ha ${ }^{-1}$ with $82 \mathrm{~kg} \mathrm{ha}^{-1}$ of $\mathrm{P}$.

The marketable head yield was adjusted by $10 \%$ adjustment coefficient and the marginal rate of return (MRR) and net benefits are calculated by current Urea price was $15 \mathrm{~kg}^{-1}$, NPS $17 \mathrm{~kg}^{-1}$ and field price of cabbage was 4.00 birr kg $^{-1}$.

Table 8. Cost Benefit Analysis of Cabbage Production.

\begin{tabular}{|c|c|c|c|c|c|}
\hline Treatments & Adjusted yield (t ha') & Gross Benefit (Birr ha $\left.{ }^{-1}\right)$ & Total variable cost (Birr ha $\left.{ }^{-1}\right)$ & Net Benefit (Birr ha $\left.{ }^{-1}\right)$ & MRR \\
\hline N1P1 & 24.894 & 99576 & 1200 & 98376 & 0 \\
\hline $\mathrm{N} 1 \mathrm{P} 2$ & 27.657 & 110628 & 2794 & 107834 & 5.9335 \\
\hline N1P3 & 30.384 & 121536 & 3470 & 118066 & 15.1361 \\
\hline $\mathrm{N} 1 \mathrm{P} 4$ & 32.4 & 129600 & 3946 & 125654 & 15.9412 \\
\hline $\mathrm{N} 2 \mathrm{P} 1$ & 35.928 & 143712 & 4122 & 139590 & 79.1818 \\
\hline $\mathrm{N} 2 \mathrm{P} 2$ & 43.389 & 173556 & 4262 & 169294 & 212.171 \\
\hline $\mathrm{N} 2 \mathrm{P} 3$ & 50.04 & 200160 & 6117 & 194043 & 13.3418 \\
\hline N3P1 & 36.459 & 145836 & 6708.75 & 139127 & $\mathrm{D}$ \\
\hline $\mathrm{N} 3 \mathrm{P} 2$ & 62.1 & 248400 & 6944 & 241456 & 434.979 \\
\hline $\mathrm{N} 3 \mathrm{P} 3$ & 60.3 & 241200 & 7220 & 233980 & $\mathrm{D}$ \\
\hline N3P4 & 53.154 & 212616 & 7496 & 205120 & $\mathrm{D}$ \\
\hline N4P1 & 40.374 & 161496 & 7663 & 153833 & D \\
\hline N4P2 & 51.147 & 204588 & 7857 & 196731 & D \\
\hline N4P3 & 45.243 & 180972 & 8133 & 172839 & $\mathrm{D}$ \\
\hline N4P4 & 43.2 & 172800 & 8609 & 164191 & D \\
\hline
\end{tabular}

Where, $\mathrm{t}=$ tone, ha $=$ hectare and $\mathrm{MRR}=$ marginal rate of return, $\mathrm{D}=$ dominance.

\section{Conclusions and Recommendation}

The present study was initiated to assess the effects of different levels of nitrogen and phosphorus on yield and yield components of head cabbage. Accordingly, four levels of $\mathrm{N}$ and four levels of phosphorus fertilizer were evaluated at Bore, southern Ethiopia in $4 \mathrm{X} 4$ factorial arrangements using randomized complete block design with three replications on a plot size of $3.0 \mathrm{~m} \times 2.4 \mathrm{~m}$ per treatment unit. Cultivation aspects such as nutrient requirements are vital in maximization of cabbage head yields. It is therefore, important for the end user to determine the best combination of optimum nitrogen and phosphorus levels.

The results of the experiment indicated a significant response of nitrogen and phosphorus with respect to growth and yield characters of head cabbage. Balanced use of nitrogen and phosphorus significantly increased the head mass, diameter and head yield and reduced the percentage of deformed head as well as percentage of unmarketable head compared to lower dose of nitrogen and phosphorus. Hence, the application of $235 \mathrm{~kg}$ nitrogen with $82 \mathrm{~kg}$ phosphorus ha ${ }^{-1}$ (N3P2) was found beneficial for growth and yield of head cabbage under highland areas of Bore.

Based on cost benefit analysis the highest net benefit 241456 birr was obtained from treatment combinations of $235 \mathrm{~kg}$ nitrogen with $82 \mathrm{~kg}$ phosphorus $\mathrm{ha}^{-1}$ with a marginal rate of return of 434.98 . Therefore the most attractive rates for the producers with low cost of production and higher benefits in this case were treatment combination of $235 \mathrm{~kg}$ nitrogen with $82 \mathrm{~kg}$ phosphorus ha ${ }^{-1}$.

\section{Conflict of Interest}

We declare that we have no competing interests.

\section{Acknowledgements}

We thank the Oromia Agricultural Research Institute for 
funding the trial. We also thank the scientists from Bore Agricultural Research Center for their management and supervisory visits to the trial sites/fields in the study area.

\section{References}

[1] Adler, P. R., Dufault, R. J. and Waters, L. J., 1984. Influence of nitrogen, phosphorous and potassium on asparagus transplant quality. Horticulture Science 19, 565-566.

[2] Askew, D., 1999. Cabbage series: Part V: Plant population, transplanting, irrigation and crop rotation. Hygrotech Forum. Newsletter of Hygrotech Seed (Pty) Ltd, Pretoria.

[3] Brady, N. C. 2003. The Nature and Properties of Soil. Macmillan Publishing Company, New York and Collier Macmillan Publishers, London. 203Pp.

[4] Brandi Marcene, 2019. 14 Amazing Health Benefits of Cabbage. Food and Nutrition. Accessed at https://www.naturalfoodseries.com/food-nutrition/march 19, 2020.

[5] Chand, S., Anwar, M. and Patra, D. D., 2006. Influence of long-term application of organic and inorganic fertilizer to build up soil fertility and nutrient uptake in mint-mustard cropping sequence. Communications in Soil Science and Plant Analysis, 37: 63-76.

[6] CIMMYT (The International Maize and Wheat Improvement Center), 1988. From Agronomic Data to Farmers Recommendations: An Economics Training Manual. Completely Revised Edition. Mexico, D. F. ISBN 968-61 27-18-6.

[7] Din, M., M. Qasim and M. Alam. 2007. Effect of different levels of $\mathrm{n}, \mathrm{P}$ and $\mathrm{K}$ on the growth and yield of cabbage. Journal of Agricultural Research. 45 (2): 171-176.

[8] EVERAARTS, A. P. and DE MOEL, C. P., 1998. The effect of nitrogen and the method of application on yield and quality of white cabbage. European Journal of Agronomy 9, 203-211.

[9] Fertilizer Society of South Africa, 2003. The fertilizer handbook. Organic fertilizers 15th edition. Foskor Publisher, Lynwood Ridge, South Africa, 15: 12-27.

[10] Hadfield, J., 1995. Vegetable gardening in South Africa. Struikh of Publishers, Cape Town, South Africa.

[11] Hemy, C., 1984. Growing vegetables in South Africa. Macmillan, South Africa (Publishers) (Pty) Ltd, Johannesburg, South Africa.

[12] Horticoop Ethiopia PLC, 2020. Bore Agricultural research Center soil analysis certificate. Bishoftu Ethiopia.

[13] Hossain D, Haque M, Abuyusuf M, Riad M, Hussain A. 2011. Response of cabbage to different levels of fertilizer application in Salna clay loam soil. Bangladesth Res Pub J 6: 155-166.

[14] Ishtiaq M. and Ullah J., 2001. Response of Chinese cabbage cultivars to different levels of nitrogen with constant doses of phosphorus and potassium. Sar J Agri 17 (1): 81-85.

[15] Kaur, K., Kapoor, K. K. and Gupta, A. P., 2005. Impact of organic manures with and without mineral fertilizers on soil chemical and biological properties under tropical conditions. Journal of Plant Nutrition and Soil Science, 168: 117-122.
[16] Krezel, J. and Koota, E., 2004. The effect of nitrogen fertilization on yield and biological value of Chinese cabbage grown from seed growing for autumn harvest. Folia Universitatis Agriculturae Stetinensis Agricultura 95: 197200.

[17] Lecuona, A., 1996. The influence of various spacing on yields and head mass of six cabbage cultivars. Roodeplaat Bulletin No. 46.

[18] Lešić, R., Borošić, J., Buturac, I., Herak-Ćustić, M., Poljak, M. and Romić, D., 2004. Povrćarstvo. Zrinski d. d. Čakovec.

[19] Marschner, H. 1994. Mineral Nutrition in Higher Plants. Academic Press. Harcout Brace. Jovanovish Puplisher. Pp. 6-74.

[20] Melton, R. R. and Dufault, R. J., 1991. Nitrogen, phosphorus and potassium fertility affect tomato transplant growth. Horticultural Science, 26 (2): 141-142.

[21] Moniruzzaman, M. S., M. M. Rahman and M. R. Islam, 2006. Effect of NPK on Growth and yield of Broccoli in southeast hilly areas of Bangladesh. Bangladesh Journal of Agriculture. 31 (1 and 2): 19-25.

[22] Neethu TM, Tripathi SM, Narwade AV and Sreeganesh S., 2015. Effect of $\mathrm{N}$ and $\mathrm{P}$ levels on growth and yield parameters of broccoli (Brassica oleracea L. var.) under South Gujarat soil conditions, International Journal of Tropical Agriculture 33: 913-917. http://www.cabdirect.org/abstracts/20153336357.html.

[23] PARMAR, H. C., MALIWAL, G. L., KASWALA, R. R. and PATEL, M, L., 1999. Effect of irrigation, nitrogen and spacing on yield of cabbage. Indian J. Hort. 56 (3), 256-258.

[24] Pavla, B. and Pokluda, R. 2008. Influence of Alternative Organic Fertilizers on the Antioxidant Capacity in Head Cabbage and Cucumber. Notulae Botanicae Horti Agrobotanici Cluj, 36 (1), 63-67.

[25] PECK, N. H., 1981. Cabbage plant response to nitrogen fertilization. Agronomy Journal 73, 679-684.

[26] Sanderson, K. R. and Ivany, J. A. 1999. Cole crop yield response to reduced nitrogen rates. Canadian Journal of Plant Science, 79: 149-151.

[27] SAS (Statistical Analytical System). 2003. SAS/STAT users Guide for Personal Computers Version (9.1.3: SAS-Institute. Cary, North Carolina.

[28] Singh MK, Chand T, Kumar M, Singh KV, Lodhi SK, Singh VP, Singh SV., 2015. Response of Different Doses of NPK and Boron on Growth and Yield of Broccoli (Brassica oleracea L. var. italica), International Journal of Bio-resource and Stress Management, 6 (1): 108-112. DOI: 10.5958/09764038.2015.00016.0.

[29] Smith, K., 1995. Classic vegetable catalogue. Thomas C. Lothian Pty. Ltd. Victoria, Australia.

[30] Solomon T., Tamado T. and Wassu M., 2018. Response of Head Cabbage (Brassica oleracea L.) to Different Rates of Inorganic Nitrogen Fertilizer and Farmyard Manure at Bore, Southern Oromia, Ethiopia. International Journal of Current Research and Academic Review. Vol. 6, No. 12, 2018, pp. 1436. doi: https://doi.org/10.20546/ijcrar.2018.612.003.

[31] Splittstoesser, W. E., 1979. Vegetable growing handbook. The AVI Publishing Company, Inc., USA. 
[32] Supe V. S and Marbhal S. K., 2008. Effect of organic manure with graded levels of nitrogen on growth and yield of cabbage (Brassica oleracea var. capitata L.). Asian Journal of Horticulture 3 (1): 48-50.

[33] The Fertilizer Institute, 2020. Fertilizer 101: The Big 3Nitrogen, Phosphorus and Potassium. Accessed at https://www.tfi.org/the-feed/. Washington D. C. 2020.

[34] Thomas, J. R., Namken L. N. and Brown R. G., 1970. Yield of cabbage in relation to nitrogen and water supply. Proceeding of American Society Horticultural Science. 95: 732-735.

[35] Tiwari, K. N., Singh, P. K. and Mal, P. K., 2003. Effect of drip irrigation on yield of cabbage (Brassica oleracea L.) under mulch and non-mulch conditions. Agricultural Water Management. 58: 19-28.
[36] WARE, G. W. and Mccollum, J. P., 1980. Producing vegetable crops. The Interstate Printers and Publishers, Inc. Illinois, USA.

[37] Westerveld, S. M., Mcdonald, M. R., Mckeown, A. W. And Scott-Dupree, C. D., 2003. Optimum nitrogen fertilization of summer cabbage in Ontario. Acta Horticulture. 627, 211-215.

[38] Yamaguchi, M., 1983. World vegetables. The AVI Publishing Company, Inc. USA.

[39] Zebarth, B. J., Freyman, S. and Kowalenko, C. G., 1991. Influence of N Fertilization on Cabbage Yield, head nitrogen content and exchangeable soil organic $\mathrm{N}$ at harvest. Canadian Journal of Plant Science. 71, 1275-1280. 